\title{
Correlations between Soluble Sugar and Phenol Contents in Leaves and Pear Scab Resistance
}

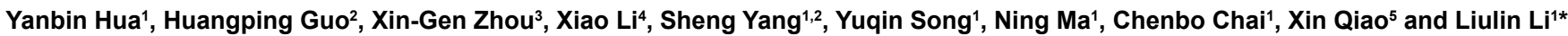

${ }^{1}$ College of Horticulture, Shanxi Agricultural University, Taigu 030801, Shanxi, P. R. China

${ }^{2}$ Pomology Institute, Shanxi Academy of Agricultural Sciences, Taigu 030815, Shanxi, P. R. China

${ }^{3}$ Agrilife Research and Extension Center, Texas A\&M University System, Beaumont, TX 77713, USA

${ }^{4}$ Shijiazhuang Pomology Institute, Hebei Academy of Agricultural and Forestry Sciences, Shijiazhuang 050061, Hebei, P. R. China

${ }^{5}$ College of Horticulture, Nanjing Agricultural University, Nanjing 210095, Jiangsu, P. R. China

\begin{abstract}
Pear scab caused by Venturia nashicola is one of the most important diseases in pears in China. Better understanding of the relationships between soluble sugar and phenol contents in the leaves and pear scab will assist in developing resistant cultivars for management of this disease. However, such relationships were poorly understood. In this study, we determined soluble sugar and total phenol contents in the leaves of 29 pear cultivars with varying levels of scab resistance in May, June, August and September of 2012 and related their levels to pear scab resistance. Results of this study demonstrated that: 1) the changes in soluble sugar and total phenol contents in the leaves of interspecific pears appeared to be relatively stable in May, June and August. In September, however, significant changes in their levels were observed. The levels of soluble sugar content in the leaves of Pyrus bretschnrideri and $P$. communis were significantly lower. Total phenol content in the $P$. communis leaves reached the highest. 2) Differences in soluble sugar and total phenol contents in the leaves of pear cultivars with varying levels of scab resistance were insignificant in May, June, August, and September. Total phenol content in pear cultivars that were immune to scab was slightly higher than that in other resistant cultivars in May, June, August, and September. 3) Soluble sugar and total phenol contents in the leaves of different interspecific and scab-resistant cultivars had no significant correlations with scab incidence in May, June, August and September. 4) There was a negatively correlation ( $p=0.039, r=-0.386$ ) between soluble sugar content in the leaves of different cultivars and scab incidence in August.
\end{abstract}

Keywords: Pear scab; Soluble sugar content; Total phenol content

\section{Introduction}

The genus Pyrus L. in the Rosaceae family is cultivated in the temperate regions of the world. China is one of the origins of this genus and has diverse cultivars and genotypes. Pear has become an important industry in China. However, pear diseases are one of the major factors limiting the pear production. Pear scab caused by Venturia nashicola is one of the most important diseases in the southern and northern pear-producing areas of China as well as in the North America. Among more than 80 diseases reported in pear, pear scab is the number one disease causing significant damage to pear in China [1,2]. Pear scab can damage stems, petioles and apical shoots at the stages of flowering through maturity. The disease causes deformity and failure of uniform fruit enlargement. Stem infection by $V$. nashicola also reduces yield and quality in the following year. In epidemic years, the disease is able to cause up to $90 \%$ of leaves infected and $50 \%$ to $70 \%$ fruit diseased [3].

Genetic resistance can be the most effective means to manage pear scab. Better understanding of the relationships between soluble sugar and phenol contents and pear scab resistance will assist in developing resistant cultivars. However, such relationships remain largely unknown. Phenolic compounds are among the most common compounds found in fruits and vegetables [4]. Production of phenolic compounds plays a role in plant genetic resistance against pathogen infection [5]. Production and accumulation of phenolic compounds occur in plant tissue where pathogens infect. Changes in the levels of phenolic compounds are frequently associated with susceptibility or resistance to plant diseases including apple scab (V. inaequalis) [59]. The levels of phenolic content in the apple fruit of scab-resistant cultivars have been shown to be significantly higher than in susceptible cultivars [6]. Sugar content in the fruits may also vary with fruit species and cultivars [10]. However, changes in phenol and sugar contents in the leaves of pear and their associated scab resistance are unknown. In this study, we focused on determining soluble sugar and total phenol contents in the leaves of 29 pear cultivars and their correlations with pear scab resistance. Understanding of the relationships between soluble sugar and phenol contents in the leaves, rather than in the fruit, and pear scab will shorten the selection process of developing resistant cultivars for management of pear scab.

\section{Experiment design}

This study was conducted as random experimental design in a 10-year-old pear tree orchard at the Pomology Institute, Shanxi Academy of Agricultural Sciences, Shanxi, China. This orchard consisted of 29 pear cultivars with different scab resistance within different interspecies (Table 1). Fifty fully-expanded leaves per tree were collected on the $15^{\text {th }}$ of May, June, August and September in 2012. There were four trees (replicates) per treatment. Leaves collected from the trials were rated

*Corresponding author: Liulin Li, College of Horticulture, Shanxi Agricultura University, Taigu 030801, Shanxi, P. R. China, Tel: +86 354 6285908; E-mail: tgliulin@163.com

Received: December 13, 2013; Accepted December 29, 2013; Published January 04, 2014

Citation: Hua Y, Guo H, Zhou XG, Li X, Yang S, et al. (2014) Correlations between Soluble Sugar and Phenol Contents in Leaves and Pear Scab Resistance. J Plant Pathol Microbiol 5: 213. doi:10.4172/2157-7471.1000213

Copyright: (c) 2014 Hua Y, et al. This is an open-access article distributed unde the terms of the Creative Commons Attribution License, which permits unrestricted use, distribution, and reproduction in any medium, provided the original author and source are credited. 
Citation: Hua Y, Guo H, Zhou XG, Li X, Yang S, et al. (2014) Correlations between Soluble Sugar and Phenol Contents in Leaves and Pear Scab Resistance. J Plant Pathol Microbiol 5: 213. doi:10.4172/2157-7471.1000213

\begin{tabular}{|c|c|c|c|c|}
\hline Cultivar & Species & $\begin{array}{l}\text { Disease } \\
\text { index }\end{array}$ & $\begin{array}{l}\text { Disease } \\
\text { incidence }\end{array}$ & $\begin{array}{l}\text { Disease } \\
\text { resistance rank }\end{array}$ \\
\hline Red Bartlett & P.communis Linn. & 0 & 0 & immune \\
\hline Lvbaoshi & P. hybrid & 0 & 0 & immune \\
\hline Abate Fetel & P. communis Linn. & 0 & 0 & immune \\
\hline Hongxiangsu & P. hybrid & 3.6 & $23 \%$ & highly resistant \\
\hline Jinzaosu & P. hybrid & 3.3 & $21 \%$ & highly resistant \\
\hline $\begin{array}{l}\text { Early Red Du } \\
\text { Comice }\end{array}$ & P. communis Linn. & 4.6 & $27 \%$ & highly resistant \\
\hline Jinmi & P. hybrid & 4.2 & $25 \%$ & highly resistant \\
\hline Jinfeng & P. bretschnrideri Rehd. & 2.3 & $18 \%$ & highly resistant \\
\hline Meirensu & P. hybrid & 4.9 & $29 \%$ & highly resistant \\
\hline Yusu & P. hybrid & 4.4 & $26 \%$ & highly resistant \\
\hline Huangguan & P. hybrid & 4.0 & $24 \%$ & highly resistant \\
\hline Jinsu & P. hybrid & 5.9 & $33 \%$ & moderately resistant \\
\hline Bayuehong & P. hybrid & 6.7 & $35 \%$ & moderately resistant \\
\hline Dangshansuli & P. bretschnrideri Rehd. & 7.6 & $38 \%$ & moderately resistant \\
\hline $\begin{array}{l}\text { Whangkeum- } \\
\text { bae }\end{array}$ & $\begin{array}{l}\text { P. pyrifolia Burm } \\
\text { Nakai. }\end{array}$ & 6.4 & $34 \%$ & moderately resistant \\
\hline Yuluxiang & P. hybrid & 10.3 & $38 \%$ & moderately susceptible \\
\hline Housui & $\begin{array}{l}\text { P. pyrifolia Burm } \\
\text { Nakai. }\end{array}$ & 12.6 & $40 \%$ & moderately susceptible \\
\hline Mantianhong & P. hybrid & 13.4 & $43 \%$ & moderately susceptible \\
\hline Zaomeisu & P. hybrid & 12.3 & $40 \%$ & moderately susceptible \\
\hline Qiyuesu & P. hybrid & 11.7 & $38 \%$ & moderately susceptible \\
\hline Zaosu & P. hybrid & 14.2 & $45 \%$ & moderately susceptible \\
\hline Kousui & $\begin{array}{l}\text { P. pyrifolia Burm } \\
\text { Nakai. }\end{array}$ & 15.7 & $47 \%$ & moderately susceptible \\
\hline Pingguoli & P. bretschnrideri Rehd. & 23.2 & $63 \%$ & highly susceptible \\
\hline Yali & P. bretschnrideri Rehd. & 26.3 & $68 \%$ & highly susceptible \\
\hline Shuofeng & P. hybrid & 24.2 & $64 \%$ & highly susceptible \\
\hline Zhongxiang & P. bretschnrideri Rehd. & 25.2 & $67 \%$ & highly susceptible \\
\hline Bayuesu & P. hybrid & 22.3 & $62 \%$ & highly susceptible \\
\hline Xuehuali & P. bretschnrideri Rehd. & 21.1 & $62 \%$ & highly susceptible \\
\hline Fali & P. communis Linn. & 23.3 & $64 \%$ & highly susceptible \\
\hline
\end{tabular}

Table 1: Scab disease index, disease incidence and scab resistance rank of 29 pear cultivars used in this study.

individually using the following scale: $0=$ no symptoms, $1=<5 \%$ of leaf area affected, $2=5$ to $14 \%$ of leaf area affected, $3=15$ to $24 \%$ of leaf area affected, $4=25$ to $34 \%$ of leaf area affected, and $5=\geq 35 \%$ of leaf area affected. Based on disease ratings, disease incidence was calculated as the percentage of the leaves showing symptoms of scab. Disease index was also calculated as follow: Disease index $=\sum$ [number of leaves with same rating scale $\times$ value of the corresponding scale]/[total number of leaves rated $\times$ greatest value of scale $] \times 100$. Cultivar scab resistance was ranked based on the following scale: immune $=0 \leq$ disease index $<1$, highly resistant $=1 \leq$ disease index $<5$, moderately resistant $=5 \leq$ disease index $<10$, moderately susceptible $=10 \leq$ disease index $<20$, and highly susceptible $=$ disease index value $\geq 20$. Collected leaves were stored in a freezer $\left(-20^{\circ} \mathrm{C}\right)$ for 24 hours. The leaves were washed in water containing 5\% laundry detergent and rinsed three times in distilled water, and blot dried with filter paper. The washed leaves were dried at $105^{\circ} \mathrm{C}$ for $30 \mathrm{~min}$ and then at $80^{\circ} \mathrm{C}$ for $24 \mathrm{~h}$. The dried leaves were crushed, screened, and preserved in desiccators.

The contents of soluble sugar and total phenols in the treated leaves were determined separately. Soluble sugar content was determined using the Yemm and Willis' method [11]. Treated leaves $(0.12 \mathrm{~g})$ were placed in $10 \mathrm{~mL}$ of deionized water, boiled for $30 \mathrm{~min}$ and then centrifuged under $12000 \times \mathrm{g}$ for $10 \mathrm{~min}$, repeated 3 times. The resulting extracts were dissolved in $50 \mathrm{~mL}$ deionized water and determined in the anthrone reagent composing of anthrone $(0.15 \mathrm{~g})$, oil of vitriol (84 $\left.\mathrm{cm}^{3}\right)$ and $\mathrm{H}_{2} \mathrm{O}\left(16 \mathrm{~cm}^{3}\right)$. The rate of absorbance $(0.1 \mathrm{~mL}$ of the extracts and $3 \mathrm{~mL}$ of anthrone reagent) was recorded at $620 \mathrm{~nm}$. Total soluble phenols in the treated leaves were extracted with $80 \%$ of methanol and quantified using the Folin-Ciocalteu method with gallic acid as a standard with detection at $750 \mathrm{~nm}$ [12]. Data were analyzed by analysis of variances (ANOVA) and treatment means were separately by the LSD test at $P=0.05$ with SPSS. Correlation analyses were also performed with SPSS.

\section{Results}

\section{Differences in the contents of soluble sugar and total phenols in the leaves of different pear interspecies}

The soluble sugar content in the leaves of interspecies remained relatively stable in May, June and August, and increased dramatically in September when the soluble sugar content in P. pyrifolia reached the highest $(83.3 \mathrm{mg} / \mathrm{g}$ ) (Table 2). On the other hand, soluble sugar content in P. pyrifolia was not significantly different from those in P. communis, P. hybrid and P. bretschnrideri.

The content of total phenols in the leaves of different interspecies were insignificant different in May, June and August. In September, the content of total phenols in P. communis reached the highest $(8.7$ $\mathrm{mg} / \mathrm{g}$ ) (Table 3), and were not significantly different from those in $P$. bretschnrideri and $P$. hybrid. There was no difference in the content of total phenols in P. bretschnrideri, P. pyrifolia and P. hybrid.

\section{Differences in the contents of soluble sugar and total phenols in the leaves of different scab-resistant cultivars}

The levels of soluble sugar contents of soluble sugar in leaves varied with different scab-resistant cultivars (Figure 1). However, there were statistically insignificant in soluble sugar content in different scabresistant cultivars in May, June, August and September.

In general, the levels of total phenol content in leaves were not statistically different among different scab-resistant cultivars evaluated in May, June, August and September (Figure 2). However, the scab-

\begin{tabular}{|l|l|l|l|l|}
\hline Species & \multicolumn{4}{|l|}{ Soluble sugar content $(\mathbf{m g} / \mathbf{g})$} \\
\cline { 2 - 5 } & May & June & August & September \\
\hline $\begin{array}{l}\text { P. bretschnrideri } \\
\text { Rehd. ( } \mathrm{n}=6)\end{array}$ & $37.4 \pm 3.7 \mathrm{a}$ & $26.8 \pm 3.9 \mathrm{a}$ & $43.0 \pm 3.3 \mathrm{a}$ & $68.1 \pm 4.4 \mathrm{~b}$ \\
\hline $\begin{array}{l}\text { P. pyrifolia Burm } \\
\text { Nakai. (n=3) }\end{array}$ & $23.4 \pm 4.4 \mathrm{a}$ & $32.0 \pm 3.5 \mathrm{a}$ & $52.6 \pm 12.2 \mathrm{a}$ & $83.3 \pm 4.4 \mathrm{a}$ \\
\hline $\begin{array}{l}\text { P. communis Linn. } \\
\text { (n=4) }\end{array}$ & $39.1 \pm 9.5 \mathrm{a}$ & $30.0 \pm 6.2 \mathrm{a}$ & $50.5 \pm 12.4 \mathrm{a}$ & $76.3 \pm 5.5 \mathrm{ab}$ \\
\hline P. hybrid $(\mathrm{n}=16)$ & $41.2 \pm 4.1 \mathrm{a}$ & $26.9 \pm 2.0 \mathrm{a}$ & $48.7 \pm 2.8 \mathrm{a}$ & $80.8 \pm 1.8 \mathrm{a}$ \\
\hline
\end{tabular}

Values in column followed by the same letter are not significantly different at $P=0.05$

Table 2: Changes in soluble sugar content (Mean \pm S.E. in $\mathrm{mg} / \mathrm{g} \mathrm{DW}$ ) in pear leaves of four different interspecies over a cropping season.

\begin{tabular}{|l|l|l|l|l|}
\hline \multirow{2}{*}{ Species } & \multicolumn{4}{|l|}{ Total phenolic content $(\mathrm{mg} / \mathrm{g})$} \\
\cline { 2 - 5 } & May & June & August & September \\
\hline $\begin{array}{l}\text { P. bretschnrideri } \\
\text { Rehd. (n=6) }\end{array}$ & $3.0 \pm 0.6 \mathrm{a}$ & $3.1 \pm 0.6 \mathrm{a}$ & $4.4 \pm 0.4 \mathrm{a}$ & $4.0 \pm 0.1 \mathrm{~b}$ \\
\hline $\begin{array}{l}\text { P. pyrifolia Burm } \\
\text { Nakai. (n=3) }\end{array}$ & $4.0 \pm 1.4 \mathrm{a}$ & $2.3 \pm 0.6 \mathrm{a}$ & $4.7 \pm 0.5 \mathrm{a}$ & $6.0 \pm 0.8 \mathrm{ab}$ \\
\hline $\begin{array}{l}\text { P. communis Linn. } \\
\text { (n=4) }\end{array}$ & $4.0 \pm 4.0 \mathrm{a}$ & $3.7 \pm 0.8 \mathrm{a}$ & $5.9 \pm 1.6 \mathrm{a}$ & $8.7 \pm 2.6 \mathrm{a}$ \\
\hline P. hybrid $(\mathrm{n}=16)$ & $2.3 \pm 2.3 \mathrm{a}$ & $2.5 \pm 0.3 \mathrm{a}$ & $4.3 \pm 0.3 \mathrm{a}$ & $3.9 \pm 0.4 \mathrm{~b}$ \\
\hline
\end{tabular}

Values in column followed by the same letter are not significantly different at $P=0.05$ Table 3: Changes in total phenolic content (Mean \pm S.E. in $\mathrm{mg} / \mathrm{g} \mathrm{DW}$ ) in pear leaves of four different interspecies over a cropping season. 
Citation: Hua Y, Guo H, Zhou XG, Li X, Yang S, et al. (2014) Correlations between Soluble Sugar and Phenol Contents in Leaves and Pear Scab Resistance. J Plant Pathol Microbiol 5: 213. doi:10.4172/2157-7471.1000213

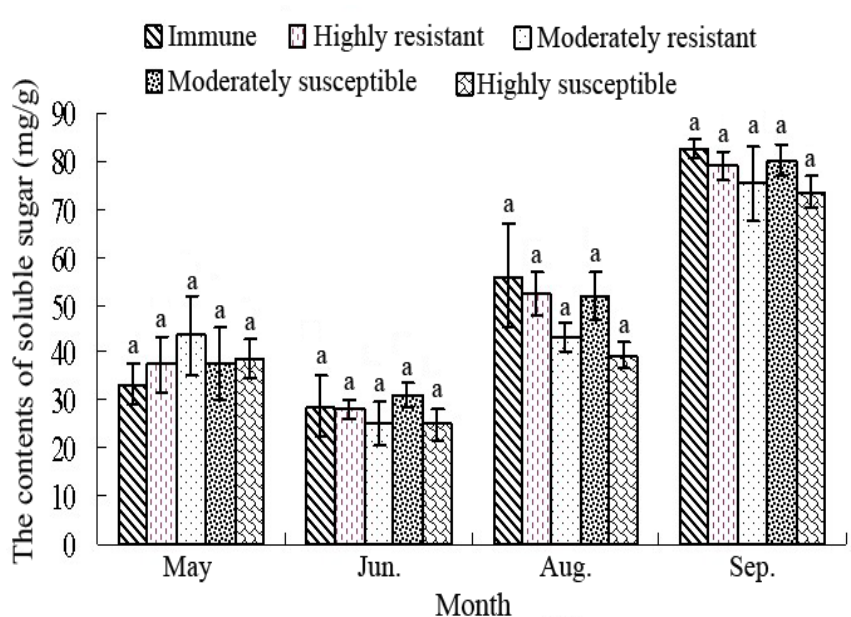

Figure 1: Changes in soluble sugar content in the leaves of different scabresistant cultivars.

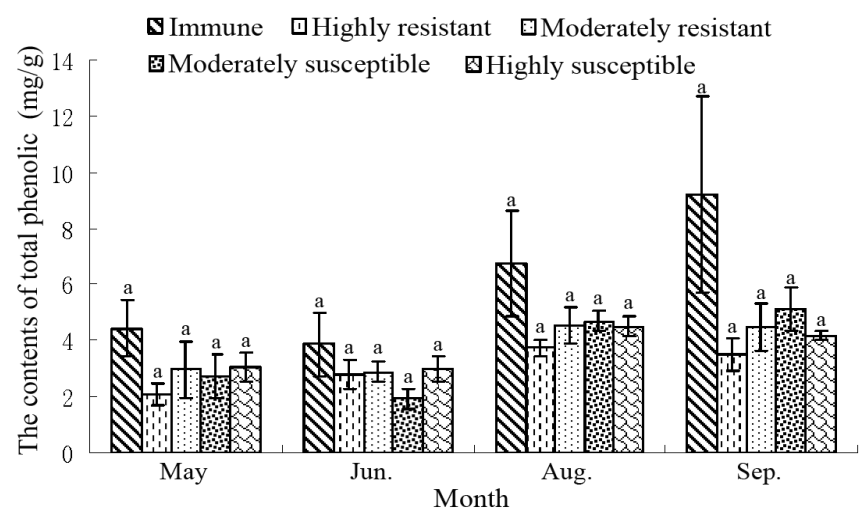

Figure 2: Changes in total phenolic content in the leaves of different scabresistant cultivars.

\begin{tabular}{|l|l|l|l|l|l|l|l|l|l|}
\hline & \multicolumn{4}{|c}{ Disease index } & \multicolumn{4}{c|}{ Disease incidence } \\
\hline & & May & June & Aug. & Sep. & May & June & Aug. & Sep. \\
\hline $\begin{array}{l}\text { Soluble } \\
\text { sugar } \\
\text { content }\end{array}$ & $\mathrm{r}$ & -0.773 & -0.838 & -0.810 & -0.787 & -0.744 & -0.773 & -0.810 & -0.787 \\
\cline { 2 - 11 } & $\mathrm{P}$ & 0.125 & 0.076 & 0.051 & 0.058 & 0.149 & 0.125 & 0.097 & 0.114 \\
\hline $\begin{array}{l}\text { Total } \\
\text { phenolic } \\
\text { content }\end{array}$ & $\mathrm{r}$ & -0.262 & 0.005 & -0.519 & -0.606 & -0.320 & -0.163 & -0.660 & -0.710 \\
\cline { 2 - 10 } & $\mathrm{P}$ & 0.670 & 0.994 & 0.370 & 0.279 & 0.599 & 0.793 & 0.225 & 0.179 \\
\hline
\end{tabular}

Note: $r$ values represent the correlation coefficients between the contents of soluble sugar or total phenols of the pear leaves and scab resistance in different interspecies, positive values represent positive correlations, whereas negative values represent negative correlations; $\mathrm{P}<0.05$ indicates significant correlations between the contents of soluble sugar or total phenols in the pear leaves of different interspecies and scab resistance

Table 4: The correlation between the contents of soluble sugar and total phenols of pear leaves and pear scab resistance in four different interspecies.

immune cultivars had the greatest levels of total phenols in each of the four months.

\section{Correlation between the contents of soluble sugar and total phenols in leaves and pear scab}

The contents of soluble sugar and total phenols were not significantly different in May, June, August and September $(\mathrm{P}>0.05)$ (Table 4), indicating that there was no correlation between the contents

\begin{tabular}{|l|l|l|l|l|l|l|l|l|l|}
\hline & \multicolumn{4}{|c|}{ Disease index } & \multicolumn{4}{|c|}{ Disease incidence } \\
\hline & & May & June & Aug. & Sep. & May & June & Aug. & Sep. \\
\hline $\begin{array}{l}\text { Soluble } \\
\text { sugar } \\
\text { content }\end{array}$ & r & 0.298 & -0.333 & -0.762 & -0.706 & 0.550 & -0.401 & -0.838 & -0.823 \\
\cline { 2 - 11 } & P & 0.627 & 0.584 & 0.135 & 0.183 & 0.337 & 0.503 & 0.076 & 0.087 \\
\hline $\begin{array}{l}\text { Total } \\
\text { phenolic } \\
\text { content }\end{array}$ & r & -0.272 & -0.406 & -0.393 & -0.493 & -0.495 & -0.556 & -0.617 & -0.710 \\
\cline { 2 - 11 } & P & 0.658 & 0.497 & 0.513 & 0.399 & 0.397 & 0.330 & 0.268 & 0.179 \\
\hline
\end{tabular}

Note: $r$ values represent the correlation coefficients between the contents of soluble sugar or total phenols of the pear leaves and scab resistance in different scab-resistant cultivars, positive values represent positive correlations, whereas negative values represent negative correlations; $\mathrm{P}<0.05$ indicates significant correlations between the contents of soluble sugar or total phenols in the pear leaves of different scab-resistant cultivars and scab resistance

Table 5: The correlation between the contents of soluble sugar and total phenols of pear leaves and pear scab resistance among five scab-resistance ranks.

\begin{tabular}{|l|l|l|l|l|l|l|l|l|l|}
\hline & \multicolumn{4}{|c|}{ Disease index } & \multicolumn{4}{c|}{ Disease incidence } \\
\hline & & May & June & Aug. & Sep. & May & June & Aug. & Sep. \\
\hline $\begin{array}{l}\text { Soluble } \\
\text { sugar } \\
\text { content }\end{array}$ & r & 0.053 & -0.133 & -0.352 & -0.251 & 0.094 & -0.133 & -0.386 & -0.286 \\
\cline { 2 - 11 } & $\mathrm{P}$ & 0.784 & 0.501 & 0.061 & 0.189 & 0.626 & 0.493 & $0.039^{*}$ & 0.133 \\
\hline $\begin{array}{l}\text { Total } \\
\text { phenolic } \\
\text { content }\end{array}$ & r & 0.271 & 0.234 & 0.234 & 0.234 & 0.242 & 0.213 & 0.190 & 0.195 \\
\cline { 2 - 10 } & & 0.155 & 0.222 & 0.205 & 0.223 & 0.205 & 0.268 & 0.324 & 0.311 \\
\hline
\end{tabular}

Note: $r$ values represent the correlation coefficients between the contents of soluble sugar or total phenols of the pear leaves and scab resistance in all 29 cultivars, positive values represent positive correlations, whereas negative values represent negative correlations; ${ }^{*} \mathrm{P}<0.05$ indicates significant correlations between the contents of soluble sugar or total phenols in the pear leaves of all 29 cultivars and scab resistance

Table 6: The correlation between the contents of soluble sugar and total phenols contents of pear leaves and pear scab resistance in all 29 cultivars evaluated.

of soluble sugar and total phenols in the leaves of different interspecies and $V$. nashicola and pear scab resistance.

The results of correlation analysis indicate that the contents of soluble sugar and total phenols were not different among different scab-resistant cultivars in May, June, August and September $(\mathrm{P}>0.05)$ (Table 5).

Correlation between the contents of soluble sugar and total phenols in the leaves of all 29 cultivars evaluated and pear scab

The contents of soluble sugar and total phenols in the leaves of all 29 cultivars evaluated and pear scab resistance were not correlated significantly with disease index or disease incidence in May, June, August and September $(\mathrm{P}>0.05)$ except one case where disease incidence was negatively correlated with soluble sugar content in August ( $\mathrm{P}=0.039, \mathrm{r}=-0.386$ ) (Table 6) .

\section{Discussion}

The current study investigated the contents of soluble sugar and total phenols in the leaves of 29 pear cultivars in relation to pear scab resistance. Results of this study show that the contents of total phenols in the immune cultivars of pear were higher than those in other diseaseresistant cultivars in May, June, August and September. These results can be explained by the findings of Luo et al. [13] that the invasion of the fungus $V$. nashicola boosted the production of free phenols in the leaves of immune pear cultivars, resulting in restrained expansion of the invasive hyphal. Furthermore, the current research also shows that the content of total phenols in the leaves of different interspecies of $P$. communis was highest in September when pear leaves were at maturity. 
Citation: Hua Y, Guo H, Zhou XG, Li X, Yang S, et al. (2014) Correlations between Soluble Sugar and Phenol Contents in Leaves and Pear Scab Resistance. J Plant Pathol Microbiol 5: 213. doi:10.4172/2157-7471.1000213

This result is in agreement with the finding of Li et al. [14] that scab resistance in pear leaves increased with the growth of leaves.

In this study, the content of soluble sugar within leaves varied significantly among different interspecies of $P$. bretschnrideri and $P$. communis in September, which is similar to Li et al. [14] findings. In the structure, physiological and bio-chemical study of pear sprout, Liu et al. [15] put forwards that the content of sugar possibly could play a significant role in disease resistance. Low soluble sugar content may retrain the growth and expansion of vegetative hyphae of $V$. nashicola between plant cells. However, the results of our study show that the content of soluble sugar in the leaves of different pear varieties had a negative correlation with disease incidence in August, which is in disagreement with Liu et al. [15] findings.

The sugar content in the pear leaves increased in September for the immune cultivars and all other resistant types with no significant difference among them. However, increased values in total phenols were observed on the immune cultivars in September but not on all other resistant types. These results suggest that determination of total phenol content in the leaves near maturity may provide a valuable tool to evaluate pear scab resistance, especially to identify the immune-type resistance. However, more investigation is needed to verify the findings from the current study.

Based on the contents of soluble sugar and total phenols in the leaves of 29 pear cultivars within different interspecies and scab resistance evaluated in this study, the contents of soluble sugar and total phenols in the leaves of different interspecies remain relatively stable in May, June and August, whereas the content of soluble sugar in $P$. bretschnrideri and P. communis had a notable change in September, when the content of total phenols in the $P$. communis leaves was highest. Meanwhile, the contents of soluble sugar and total phenols in the leaves of different disease-resistant cultivars remained relatively stable in May, June, August and September, but the immune cultivars had much higher levels than other different disease-resistant cultivars in that period. The contents of soluble sugar and total phenols in the pear leaves of different interspecies and disease-resistant cultivars had no correlation with the incurrence of pear scab resistance. The content of soluble sugar in different pear leaf varieties had a negative correlation with disease incidence in August.

\section{Acknowledgments}

This study was supported by the National High-Tech Research and Development "863" Program of China under the project of molecular breeding and cultivar innovation of pear, peach and banana (2011AA102206). Additional support was provided by the Shanxi Province Science and Technology Development Program (20130311021-2).

\section{References}

1. Luo WH (1988) Studies on pathogen and biological characters of pear scab. Journal of Sichuan Agricultural University 6: 59-64.

2. Liu C, Li JC, Xu XF, Wang Y, Li TZ, et al. (2009) The Progress on Pear Scab (Venturia nashicola). Northern Horticulture 6: 119-124.

3. Xu LF, Ma FW, Huang WJ, Zhang YB (2000) Advances in Research on Pear Scab. Chinese Agricultural Science Bulletin 16: 32-34.

4. Hertog MGS, Hollman PC, Katan MB (1992) Content of potentially anticarcinogenic flavonoids in 28 vegetables and 9 fruits commonly consumed in the Netherlands. Journal of Agricultural and Food Chemistry 40: 2370-2383.
5. Treutter D (2005) Significance of flavonoids in plant resistance and enhancement of their biosythensis. Plant Biology 7: 581-591.

6. Treutter D, Feucht W (1990) The pattern of flavan-3-ols in relation to scab resistance of apple cultivars. Journal of Horticultural Science 65: 511-517.

7. Usenik V, Mikulic-Petkovsek M, Solar A, Stampar F (2004) Flavonols of leaves in relation to apple scab resistance. Z. Pflanzenkr. Pflanzenschutz 111: 137144

8. Petkovsek MM, Stampar F, Vebric R (2007) Parameters of inner quality of apple cab resistant and susceptible apple cultivars (Malus domestica Borkh.). Scientia Horticulturae 114: 34-47.

9. Petkovsek MM, Tampar FS, Vebric R (2009) Accumulation of phenolic compounds in apple in response to infection by the scab pathogen, Venturia inaequalis. Physiological and Molecular Plant Pathology 74: 60-67.

10. Chun OK, Kim DO, Smith N, Schroeder D, Han JT, et al. (2005) Daily consumption of phenolics and total antioxidant capacity from fruit and vegetables in the American diet. Journal of the Science of Food and Agriculture 85: $1715-1724$.

11. Yemm EW, Willis AJ (1954) The estimation of carbohydrates in plant extracts by anthrone. Biochemical Journal 57: 508-514.

12. Kováčk J, Klejdus B, Štork F, Hedbavny J (2011b) Nitrate deficiency reduces cadmium and nickel accumulation in chamomile plants. Journal of Agricultural and Food Chemistry 59: 5139-5149.

13. Luo WH, Leng HQ (1990) Studies on resistance of pear varieties to pear scab (Venturia Nashicola). Journal of Sichuan Agricultural University 8: 141-146.

14. Li BH, Zhao MQ (2001) Relationship between leaf age of pear and its resistance to Venturia Nashicola. Acta Phytophylacica Sinica 28: 309-312.

15. Liu YT, Feng XJ, Xi GC, Pu BZ, Wang QL, et al. (2012) Relationships between scab resistance and leaf tissue structure and physiological characteristics of Yali pear with bud mutation. Plant Protection 38: 31-34. 